\title{
Birt Hogg Dube syndrome: Rare family lung disease
}

\author{
Şaban Melih ŞiMŞEK ${ }^{\mathbf{1}}$ (ID) \\ Recep SAVAS ${ }^{3}($ ID) \\ Peyker TEMIZ² (ID) \\ PInar ÇELIK ${ }^{1}($ ID)
}

Cite this article as: Simsek SM, Savas $R$, Temiz $P$, Celik $P$ Birt Hogg Dube syndrome: rare family lung disease. Tuberk Toraks 2021;69(1):102-106.

\section{Yazışma Adresi (Address for Correspondence)}

\section{Dr. Şaban Melih ŞiMŞEK}

Celal Bayar Üniversitesi Tıp Fakültesi, Göğüs Hastalıkları Anabilim Dalı, MANISA - TÜRKIYE

e-mail: s.melih.simsek@gmail.com

\section{CCopyright 2021 by Tuberculosis and Thorax.}

Available on-line at www.tuberktoraks.org.com
${ }^{1}$ Department of Chest Diseases, Celal Bayar University Faculty of Medicine, Manisa, Turkey

${ }^{1}$ Celal Bayar Üniversitesi Tıp Fakültesi, Göğüs Hastalıkları Anabilim Dalı, Manisa, Türkiye

${ }^{2}$ Department of Pathology, Celal Bayar University Faculty of Medicine, Manisa, Turkey

${ }^{2}$ Celal Bayar Üniversitesi Tıp Fakültesi, Patoloji Anabilim Dalı, Manisa, Türkiye

${ }^{3}$ Department of Radiology, Ege University Faculty of Medicine, İzmir, Turkey

${ }^{3}$ Ege Üniversitesi Tıp Fakültesi, Radyoloji Anabilim Dalı, İzmir, Türkiye

\begin{abstract}
Birt Hogg Dube syndrome: Rare family lung disease

Birt Hogg Dube syndrome is a rare disease characterized by autosomal dominant inherited multiple cysts in the lungs, renal tumors and skin fibrofolliculomas. It was first described in 1977 by Birt et al. In this case report, a patient who was diagnosed with symptoms and his first degree relative is presented. Diseases that should be considered in differential diagnosis are discussed. The diagnosis of this disease is usually made after recurrent pneumothorax. Since it is a genetic disease, the importance of follow-up and screening needs of patients and their relatives is emphasized.
\end{abstract}

Key words: Birt Hogg Dube syndrome; cystic lung diseases; renal tumors

\section{ÖZ}

\section{Birt Hogg Dube sendromu: Nadir görülen ailesel akciğer hastalığı}

Birt Hogg Dube sendromu, otozomal dominant kalıtılan akciğerlerde multipl kistler, renal tümörler ve deride fibrofolikülomalar ile karakterize nadir bir hastalık olup ilk kez 1977'de Birt ve arkadaşları tarafından tanımlanmıștır. Burada semptomdan tanıya gidilen bir hasta ve 1. derece yakını sunulmakta, ayırıcı tanıda düşünülmesi gereken hastalıklar tartışılmaktadır. Genellikle tekrarlayan pnömotorakslar sonrası tanı konulmaktadır. Genetik bir hastalık olması nedeniyle hasta ve yakınlarının takip ve tarama gereksinimlerinin önemi vurgulanmaktadır.

Anahtar kelimeler: Birt Hogg Dube sendromu; kistik akciğer hastalıkları; renal kanserler 


\section{INTRODUCTION}

Birt Hogg Dube syndrome (BHD) is a rare cystic lung disease. It is thought that many mutations in the folliculin gene encoding folliculin (FLCN), which is autosomal dominantly located in the $17^{\text {th }}$ chromosome (1). There are numerous cysts in the lungs, benign tumors of the hair follicle (fibrofolliculoma, trichodiscoma) and renal tumors. Recurrent pneumothorax are seen due to multiple cysts in the lung parenchyma.

In our country, 2 case series with a diagnosis of BHD were presented by Cimsit et al. (2). Here, 2 cases with multiple cysts in their lungs are presented, BHD syndrome from symptom to diagnosis is discussed.

\section{Case 1}

A 57-year-old female patient was admitted to our outpatient clinic with intermittent dyspnea on exertion. It was learned from her background that she had a 10 pack-year smoking history and had pneumothorax twice 5 years ago. It was learned that the history of pneumothorax was similar to the patient's son, sibling and uncle.

On physical examination, the patient was obese, respiratory sounds were normal and observed that there were patches of macules on the skin of the patient and skin tags on the neck. Bilateral subpleurally located multiple cystic lesions were observed in the thorax computed tomography (CT), which was taken due to the history of recurrent pneumothorax of the patient whose posteroanterior chest radiography showed increased ventilation in places (Figure 1) (Figure 2a-b).

Since the existing cystic lesions are peripherally located and subpleural, have skin lesions and have a history of common relatives, further investigation was planned considering that the patient may have BHD

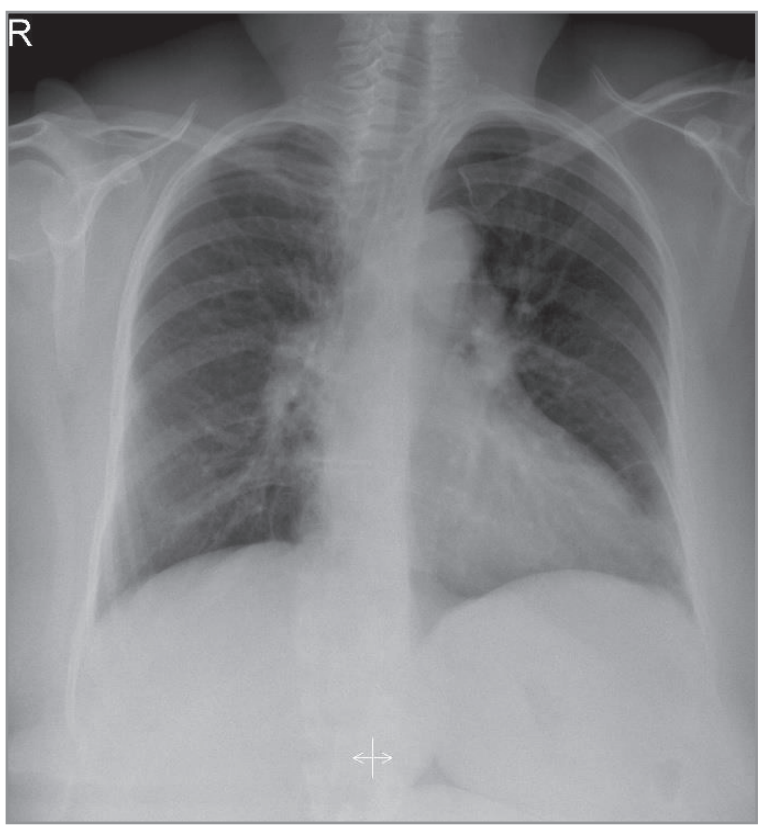

Figure 1. PA AC X-ray.

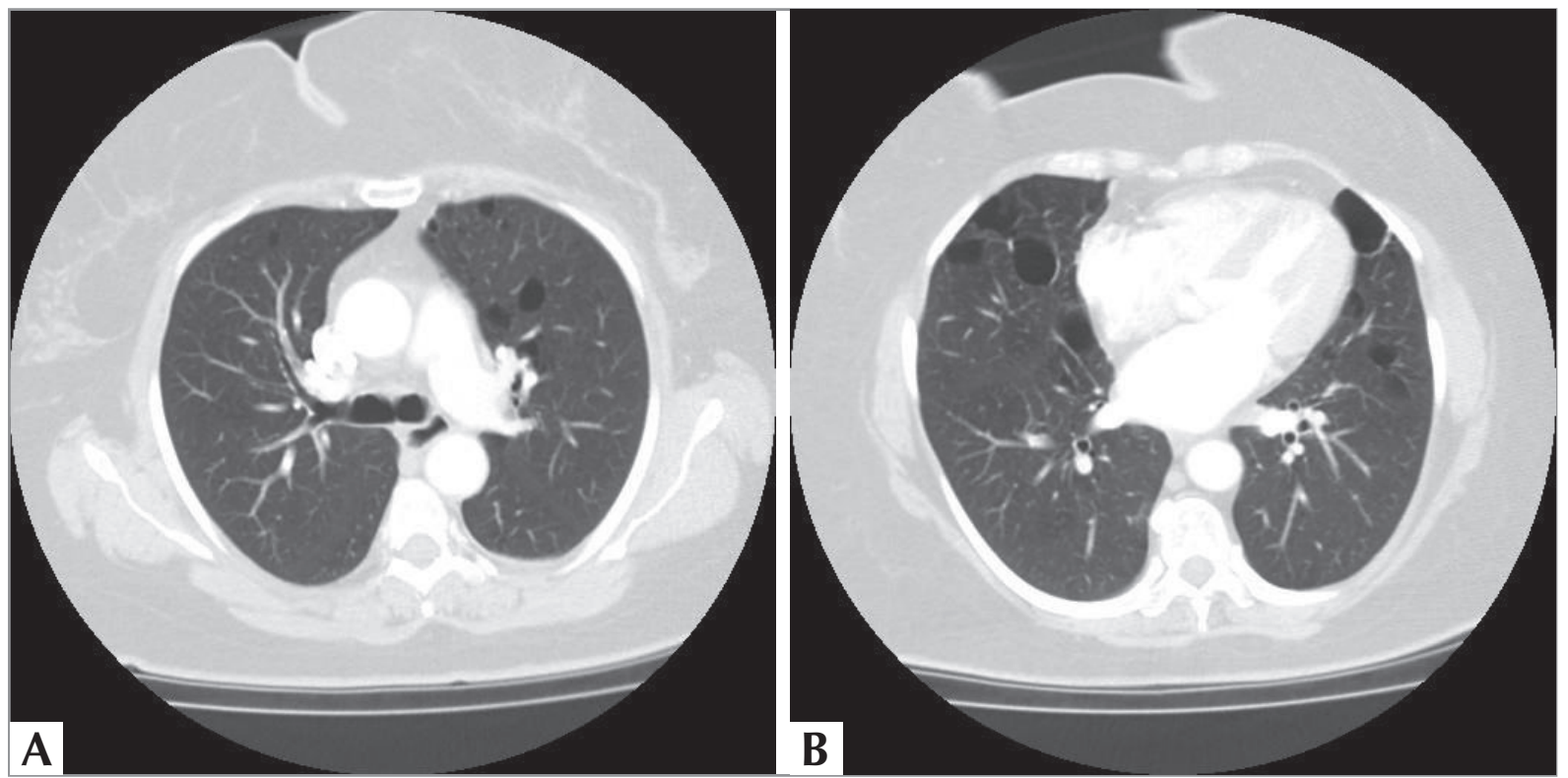

Figure 2. A.B In thoracic CT parenchyma, air cysts are seen to be located in the peripheral and subpleural section in the parenchyma. 


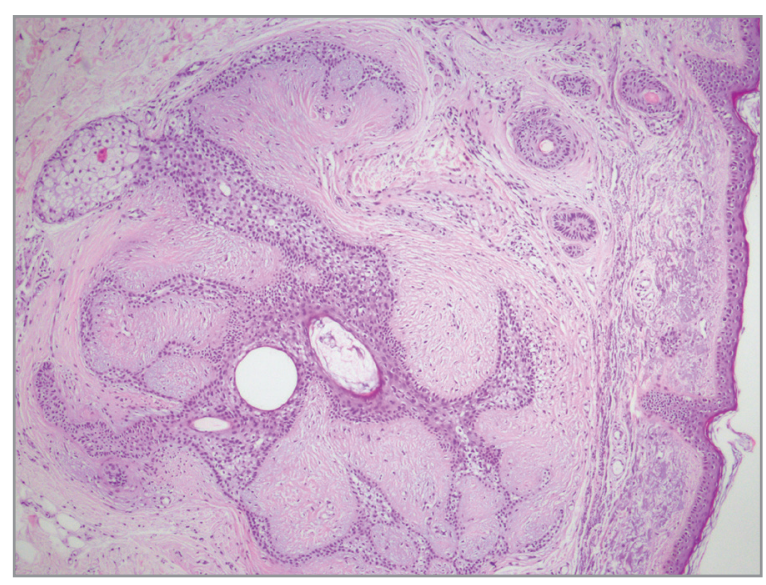

Figure 3. Well-defined nodular tumor consisting of proliferated epithelial corridors surrounded by fibrous stroma ( $\mathrm{HE}, \mathrm{x} 20)$.

syndrome first. Biopsy was performed from the skin lesions in the neck region of the patient, and the biopsy pathology resulted as fibrofolliculoma (Figure 3). A genetic examination was requested for the FLCN gene mutation, which is diagnostic for BHD syndrome, and the patient was positive for the FLCN gene mutation.

After the patient was diagnosed with BHD syndrome, an abdominal ultrasonography was performed in terms of possible renal malignancies and it was reported as normal. The patient and his family were informed about this disease and the follow-up process started.

\section{Case 2}

The son of the patient mentioned above was called to our polyclinic because his son also had a history of pneumothorax in his anamnesis. The medical history of a 33-year-old male patient who was admitted to the emergency service of our hospital with pneumothorax was questioned. A diagnosis of recurrent pneumothorax was made 1 year before, due to a history of pneumothorax and tube thoracostomy (Figure 4a-b). Later, it was learned that wedge resection and partial decortication procedure was performed with uniportal VATS in our thoracic surgery clinic. It was learned that there was no pneumothorax after this procedure. Skin lesions were not observed in the patient's examination. Abdominal ultrasonography performed for possible renal malignancies was normal. Since the diagnosis of BHD syndrome was confirmed in the mother of the patient and he had multiple cysts in the lung parenchyma and a history of pneumothorax, our patient was accepted as BHD syndrome because it met two minor diagnostic criteria. Both patients and their relatives were informed about the disease and followed up.

\section{DISCUSSION}

Although BHD syndrome is a rare syndrome, it differs from other cystic lung diseases in that it has a particularly dominant familial history. For the diagnosis of BHD syndrome, major and minor criteria recommended by the European Birt-Hogg-Dube Concert are used $(3,4)$. These criteria are shown in Table 1.

Other cystic lung diseases that should be considered primarily in the differential diagnosis are lymphangioleiomyomatosis (LAM), langerhans cell histiocytosis (LHH), lymphocytic interstitial pneumonia (LIP). LAM
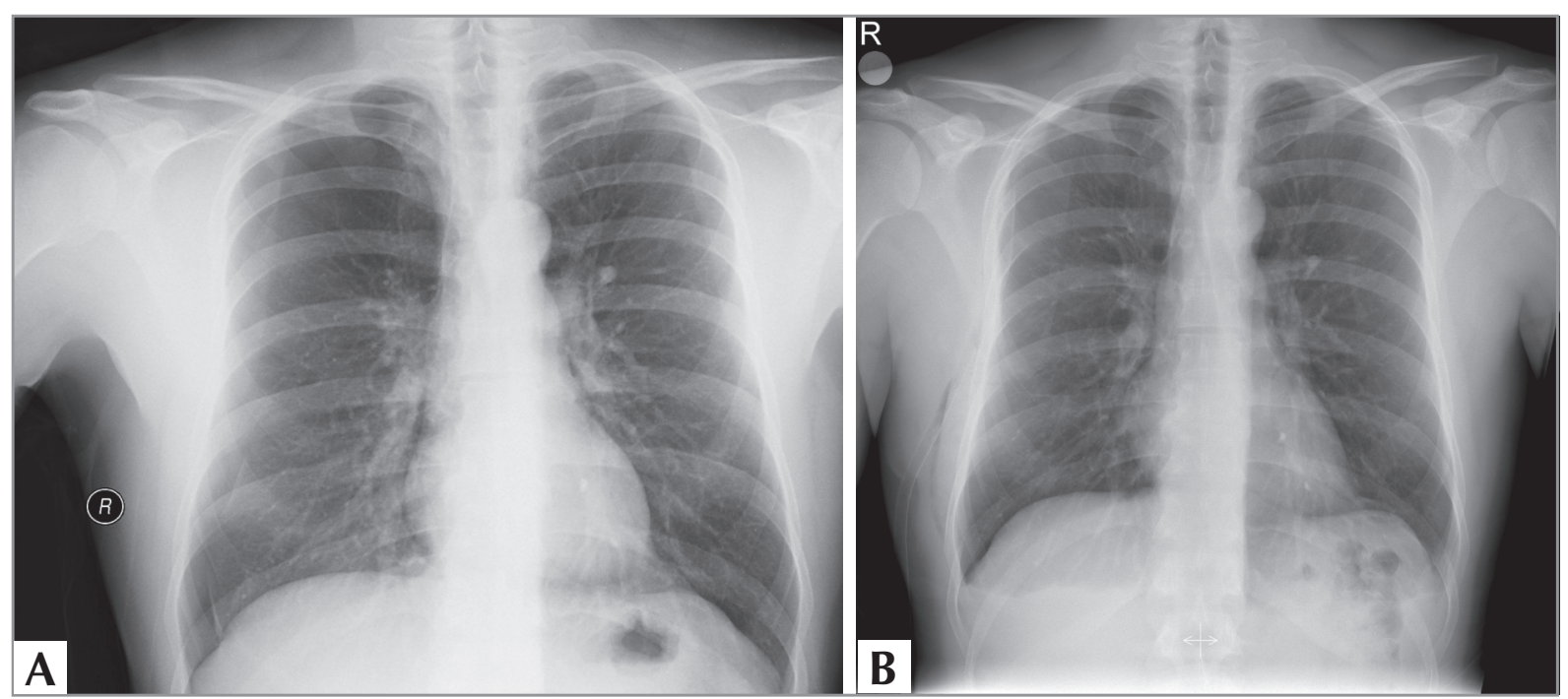

Figure 4. A. Pneumothorax is seen on the right, B. X-ray after tube thoracostomy. 
Table 1. Criteria recommended by the European Birt-Hogg-Dube Consortium for the diagnosis of Birt-Hogg-Dube syndrome

\begin{tabular}{|lc|}
\hline Major Criteria & Minor Criteria \\
\hline $\begin{array}{l}\geq 5 \text { fibrofolliculoma or trichodiscoma, of which at least one has } \\
\text { been histopathologically diagnosed in adulthood } \\
\text { Mutation in the FLCN gene }\end{array}$ & $\begin{array}{c}\text { Multiple lung cysts (Bilateral and basal localized } \pm \\
\text { spontaneous pneumothorax) }\end{array}$ \\
In order to be diagnosed with BHD, patients must meet 1 major or 2 minor criteria. & $\begin{array}{c}\text { Refore age } 50 \text { or multifocal, bilateral or mixed } \\
\text { chromophobe, oncocytic histopathology } \\
\text { Birt-Hogg-Dube syndrome in first degree relatives }\end{array}$ \\
\hline
\end{tabular}

is differentiated in female patients of childbearing age by being radiologically in the form of uniform cysts and at the costophrenic sinus level. Cysts in $\mathrm{LHH}$ are of different sizes and are irregularly shaped. These patients have a history of smoking, accompanying nodules, and it appears that the costophrenic sinuses are preserved. LIP is mostly seen in middle-aged, female patients with connective tissue disease, and there are radiologically accompanying ground glass areas. The cysts are located in thin-walled and basal parts.

BHD syndrome can be differentiated from other cystic lung diseases in that the cysts are located in different sizes on thoracic CT, especially in the lower lobes and peripheral subpleural (5). Depending on the cysts, the prevalence of pneumothorax at a rate of 8-90\% has been defined (6-8). Similarly, our second case had a history of recurrent pneumothorax.

FLCN is associated with the tumor suppressor gene associated with renal carcinogenesis (5). In BHD syndrome, renal cysts were detected in $15 \%$ due to FLCN gene inactivation, and renal tumors were detected in $29 \%$ with CT scanning $(8,10)$. Although there is no definitive follow-up scheme for these patients, scanning with ultrasonography or CT every 3-5 years is recommended (11).

Hair follicle tumors defined in BHD syndrome are benign and hamartomatous in character. Fibrofolliculomas, trichodiscomas and fibroepithelial polyps (skin tags) have been identified. These lesions are generally seen in the 30s after the age of 20 $(12,13)$

Genetic counseling is important for these patients. In addition to screening for renal cancers, patients should be informed about pneumothorax. Providing smoking cessation will also reduce the risk of pneumothorax and renal cancer. Patients and their relatives should be warned about pneumothorax for air travel and general anesthesia.

\section{CONFLICT of INTEREST}

The authors reported no conflict of interest related to this article.

\section{AUTHORSHIP CONTRIBUTIONS}

Concept/Design: PÇ

Analysis/Interpretation: ŞMŞ

Data Acquisition: ŞMŞ

Writing: ŞMŞ

Critical Revision: RS, PT

Final Approval: PÇ

\section{REFERENCES}

1. Nickerson ML, Warren MB, Toro JR, Matrosova V, Glenn G, Turner ML, et al. Mutations in a novel gene lead to renal tumors, lung wall defects, and benign tumors of the hair follicle in patients with the Birt-Hogg-Dube syndrome. Cancer Cell 2002; 2: 157-64.

2. Cimsit C, Eryuksel E, Çimşit N, Olgun S, Seckin D, Saricam $M$, et al. Birt-hogg-dubé syndrome: $C T$ findings of an under recognized disease requiring multidisciplinary approach. Respir Case Rep 5; 5-9.

3. Lopez V, Jorda E, Monteagodo C. Birt-Hogg-Dube syndrome: an up date. Actas Dermosifiliogr 2012; 103: 198206.

4. Menko FH, van Steensel MA, Giraud S, Friis-Hansen L, Richard S, Ungari S, et al. Birt-Hogg-Dubé syndrome: diagnosis and management. Lancet Oncol 2009; 10: 1199-206.

5. Toro IR, Wei MH, Glenn GM, Weinreich $M$, Toure $O$, Vocke $C$, et al. BHD mutations, clinical and molecular genetic investigations of Birt-Hogg-Dube syndrome: a new series of 50 families and a review of published reports. J Med Genet 2008; 45: 321-31.

6. Kunogi M, Kurihara M, Ikegami TS, Kobayashi T, Shindo N, Kumasaka T, et al. Clinical and genetic spectrum of BirtHogge-Dube syndrome patients in whom pneumothorax and/or multiple lung cysts are the presenting feature. J Med Genet 2010; 47: 281. 
7. Leter EM, Koopmans AK, Gille JJP, van Os TAM, Vittoz GG, David EFL, et al. Birt-Hogg-Dube syndrome: clinical and genetic studies of 20 families. Soc Inv Derm 2008; 128: 45.

8. Toro JR, Glenn G, Duray P, Darling T, Weirich G, Zbar B, et al. Birt-Hogg-Dubé syndrome: a novel marker of renal neoplasia. Arch Dermatol 1999; 135(10): 1195.

9. Toro JR, Pautler SE, Stewart L, Glenn GM, Weinreich M, Toure $O$, et al. Lung cysts, spontaneous pneumothorax, and genetic associations in 89 families with Birt-HoggDubé syndrome. Am / Respir Crit Care Med 2007; 15; 175(10): 1044-53.

10. Schmidt $L S$, Nickerson ML, Warren MB, Glenn GM, Toro $J R$, Merino MJ, et al. Linehan WM. Germline BHDmutation spectrum and phenotype analysis of a large cohort of families with Birt-Hogg-Dubé syndrome. Am J Hum Genet 2005; 76(6): 1023-33.
11. Lindor NM, Hand J, Burch PA, Gibson LE. Birt-Hogg-Dube syndrome: an autosomal dominant disorder with predisposition to cancers of the renal, fibrofolliculomas, and focal cutaneous mucinosis. Int I Dermatol 2001; 40: 6536.

12. Furuya M, Tanaka R, Koga S, Yatabe Y, Gotoda H, Takagi S, et al. Pulmonary cysts of Birt-Hogg-Dube syndrome: a clinicopathologic and immunohistochemical study of 9 families. Am I Surg Pathol 2012; 36: 589-600.

13. Shvartsbeyn $M$, Mason AR, Bosenberg MW, Ko Cl. Perifollicular fibroma in Birt-Hogg-Dube syndrome: an association revisited. J Cutan Pathol 2012; 39: 675-9. 